体重発育に拈ける季節変動とその地域性に関する研究

$$
\text { 戸部 秀之* }
$$

\title{
The Seasonal Variation of Weight Growth in School Children and Its Regional Patterns
}

\section{Hideyuki TOBE*}

The monthly body weight data of school children in different regions, the school A in urban area of Tokyo, the school B and C in rural areas of Gunma and Tochigi prefectures, were investigated in order to compare the regional patterns of seasonal variation in weight growth. The seasonal factors of each region and those of each children were calculated by a time-series analysis. The results obtained were as follows.

1) In all regional groups, the highly significant seasonality $(p<0.0001)$ were observed. The seasonal patterns of low in summer, especially in July, were the same in all regional groups. However, the months in which the high values appeared were different among the groups. The amplitudes of seasonal variation were smaller in the children of school A than in the children of school B or C.

2) From the analysis of the seasonal patterns of each child, the minimum values in seasonal factor appeared in July in many children, and it was remarkable in the children of school B and C.

3) The effects of months on variation in weight growth were different between sexes, from the fact that the $\mathrm{F}$-values in the stable seasonality test were much higher in boys than in girls.

Key words : Seasonal variation, Weight growth, Time-series analysis, Urban area, Rural area

季節変動, 体重発育, 時系列解析, 都市部, 農山村部

\section{I 緒 言}

小児の体重発育に拈ける季節変動については, これまで内外を通じて多くの報告がなされてき た. Bogin (1979)は, 温帯の衛生状態のよい地域 に住む，健康な子どもの体重の季節変動について の研究をまとめ, 秋, 冬では増加量が大きく, 春,
夏では増加量が小さいことを示した。一方，熱帯 や亜熱帯で, 公衆衛生の充実していない地域では, 雨季に百日咳, 下痢, 麻疹などの感染症の増加 (Trowbrige ら : 1979, Prentice ら : 1981, Abdullah ら : 1985, Hauspie ら : 1989, Jalil ら : 1989), また, 季節的な食料不足 (Brown ら：1982, Pollitt ら：1989）が体重の季節変動を引き起こすことが

* 東京大学教育学部健康教育学研究室

* Department of Health Education, Faculty of Education, University of Tokyo 
指摘されている.わが国においては，1940年代， 50 年代に，小学校児童を対象に検討され，秋に増 加量が大きく，春に増加量が小さい傾向が報告さ れている（高橋：1948, 小林ら：1955）.

季節変動は環境要因と身体との相互作用として 生じるものであり，環境の異なる地域間で，季節 変動のパターンや変動の大きさなどを比較検討す ることは, 発育と環境要因との関係を知るための 手がかりになる。しかしながら，1940年代，50年 代に比べ，公衆衛生が充実し，生活環境が大きく 変化した, 現在の体重発育の季節变動は報告され て抢らず，地域性を検討した報告もない. 加えて， 従来は, 季節ごとの増加量の平均値を指標として 検討される場合がほとんどであり, 季節変動の個 人別パターンなどの個人の情報は得られなかっ た。

そこで, 本研究では小学生児童の 6 年間の月次 体重計測值を用いて, 都市部と農山村部の異なる 環境下で成育している学童について，体重発育に おける季節変動の比較を，1）集団の季節変動パ ターンの比較，2）個人別の変動パターンの検討, の両視点から行った.

身体発育値から季節変動を抽出するに当たり， 発育スパートや測定誤差などの影響を少なくする ため, 移動平均法に基づく時系列解析を用いて, 1 年を周期とする季節変動成分を求めた。

\section{II 方 法}

本研究は, 東京都 A 小学校の児童を都市部に括 ける対象, 群馬県 B 小学校, 杤木県 C小学校の児 童を寒冷地農山村部に拈ける対象とした。いずれ も, 小学校入学時から卒業までの 6 年間の体重の 月次データーが得られた者とした。得られた身体 計測データは次の通りである。

東京都 A 小学校 1982年度から1984年度に入 学した児童について，夏休みにあたる 8 月を除く 毎月の体重測定值， 4 月， 9 月，1月の年 3 回の 身長測定值が得られた。人数は男子 64 名，女子 61 名, 計125名である。

群馬県 B 小学校 1983 年度掞よび1984年度に
入学した児童について，毎月の体重測定値，4月， 8 月，1月の年 3 回の身長測定值が得られた。人 数は男子 50 名, 女子 57 名, 計 107 名である。

栃木県 C小学校 1980 年度および1981年度に 入学した児童で， 8 月を除く毎月の体重測定值， 4 月， 9 月，1月の年 3 回の身長測定值が得られ た。人数は男子11名, 女子 6 名, 計17名である. 東京都 A 小学校の所在地は, 都心の通勤圏に含 まれる住宅街であり, 児童の成育環境としては, わが国の都市部の典型であると推測される。

群馬県の B 小学校のある地区は, 群馬県北西部 の標高 $800 \mathrm{~m}$ から $1,200 \mathrm{~m}$ の高原地帯であり, 総面 積の約 7 割が山林で占められる典型的な農山村で ある。気候は北海道の札幌あるいは旭川に近く， 夏でも 30 度を越劣ることはまれで，冬には一 10 度 以下になることも少なくない，村内西部はキャべ ッを中心に生産する大規模な農業地帯である。対 象は，村内東部の商店街や住宅地がある，村内で も比較的都市化された地区に住む子どもである。

栃木県 C小学校のある地区は, 栃木県北部の標 高約 $600 \mathrm{~m}$ に位置する比較的寒冷な地域である. 産業は, 農業々酪農が中心であり, 本研究の対象 者の家庭もほとんどが兼業農家，もしくは酪農を 営んでいる，気候については，冬季には－10度以 下になる場合も多く，B 小のある地域と類似して いる，交通の便は非常に悪く，都市的な環境が入 りにくい地域である。

体重データについて, データの敩密性のため, 連続した欠損值がないこと，また，夏休みによる 欠損值以外に 4 つ以上の欠損值がないことを条件 とした。これにより対象にバイアスが生じること はなかった．分析ではデータの欠損値は前後の月 の平均値として内㨀され，1 人につき 72 力月分, 計249人のデータが得られた。

本研究では, 体重の季節変動を求めるために, SAS/ETS（SAS Institute，1984）に含まれる時 系列解析，センサス局法 (Sensus method IIX11) をもちいた. 分析は, 東京大学大型計算機センター の HITAC M-880で行った。

センサス局法では, 測定データである原時系 
列；Oは，循環傾向成分（以下，トレンド成分と 寸る)；C と季節変動成分； $\mathrm{S}$ と不規則成分；I の3つの成分からなるものとされ，それらの積を 仮定する乗法モデルと, 各成分の和を仮定する加 法モデルがある，発育に持ける季節変動では, 単 なる季節変動の絶対値ではなく，現量値に対する 季節変動の割合が重要な意味を持つため, ここで は乗法モデルを用いた。

$$
\begin{aligned}
& \mathrm{O}=\mathrm{C} \times \mathrm{S} \times \mathrm{I}(\text { 乗法モデル) } \\
& \mathrm{O}=\mathrm{C}+\mathrm{S}+\mathrm{I}(\text { 加法モデル) }
\end{aligned}
$$

季節変動成分と不規則成分は, トレンド成分に対 する比率で表され，実際の単位（ここでは kg）で 表された季節变動成分 $(\mathrm{S}(\mathrm{kg}))$, 不規則成分 (I (kg)）とは次の関係をもつ.

$$
\begin{aligned}
& \mathrm{S}=100(\mathrm{~S}(\mathrm{~kg})+\mathrm{C}) / \mathrm{C} \\
& \mathrm{I}=100(\mathrm{I}(\mathrm{kg})+\mathrm{C}) / \mathrm{C}
\end{aligned}
$$

各成分について簡単に述べると次のようにな る。
トレンド成分 $(\mathrm{C})$ 原時系列 $(\mathrm{O})$ を移動平均に よって平滑化した成分である。

季節変動成分 $(\mathrm{S}) \mathrm{SI}$ 比 $(\mathrm{S} \times \mathrm{I}$ であり, 原時系 列とトレンド成分の隔たりを表す）の中で 1 年間 の周期をもつ成分である. SI 比の月別移動平均に よって求められる.

不規則成分 (I) SI 比の中で季節変動成分以外 のすべての変動が含まれる。

季節性の検定は，分散分析を用いて，SI 比にお ける月の主効果の有意性を検定することによって 行われる。センサス局法の計算過程は, 東郷 (1981)，Togo ら (1982) に詳しい. 図 1 に本研究 の被検者 2 名 $\mathrm{a}, \mathrm{b}$ の体重発育值を乗法モデルで 処理した例を示すが，トレンド成分に季節变動成 分と同調した波動が多少見られるものの，季節変 動の抽出は比較的良好であると考兄られる。

本研究では，地域間の季節変動パターンの検討 に怙いては，地域別・性別の体重平均值に対し時
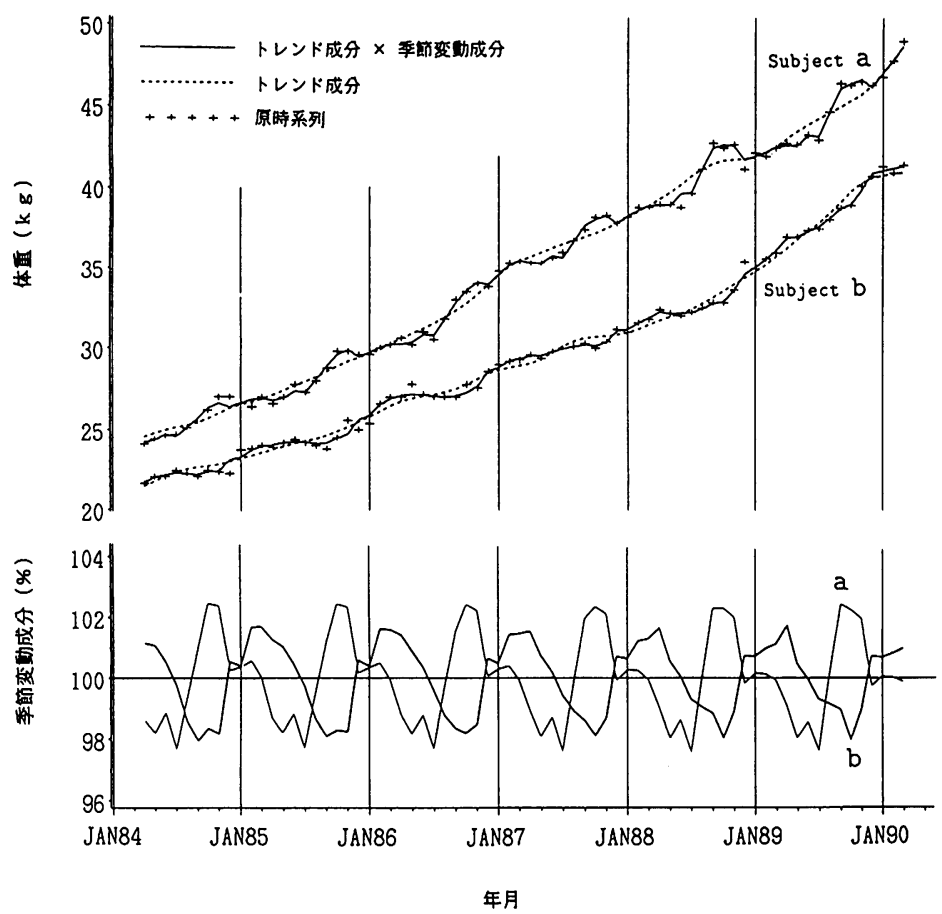

図 1 センサス局法で処理した月次体重発育データの例一被検者 $\mathrm{a}$ と b の 2 名につ いてのもの 
系列解析を行い, 季節変動成分を求め比較した. また，個人別データについても同様に時系列解析 を行い，個人別の季節変動パターンの検討に用い た。

\section{III 成 績}

1. 児童の身体特性
各地域の子どもの身体特性を表 1 にしめす。A 小児童の身長，体重，ローレル指数は，男女とも 平成元年度学校保健統計調査報告書による全国平 均值とよく一致していた， B 小児童では，身長， 体重とも全国平均値に比較的近い值をとっていた が，ローレル指数は男女とも若干高く, 弱い肥満 傾向が見られた. C小では, 男子で, 全国平均に比

表 1 各校児童の身体的特徵

\begin{tabular}{|c|c|c|c|c|c|}
\hline & & $\mathrm{A}$ 小 & B 小 & C小 & 全国平均 \\
\hline \multicolumn{6}{|c|}{ 身 長 } \\
\hline \multirow[t]{2}{*}{ 小 1 時 } & 男子 & $117.3 \pm 5.0$ & $116.2 \pm 5.2$ & $112.8 \pm 4.5$ & $116.7 \pm 4.86$ \\
\hline & 女子 & $116.0 \pm 4.7$ & $115.5 \pm 5.0$ & $117.3 \pm 4.9$ & $116.0 \pm 4.79$ \\
\hline \multirow[t]{2}{*}{ 小 6 時 } & 男子 & $144.8 \pm 6.5$ & $143.0 \pm 6.8$ & $138.1 \pm 5.2$ & $144.3 \pm 6.78$ \\
\hline & 女子 & $146.6 \pm 6.9$ & $145.7 \pm 7.1$ & $148.4 \pm 8.2$ & $146.1 \pm 6.60$ \\
\hline \multicolumn{6}{|c|}{ 体 重 } \\
\hline \multirow[t]{2}{*}{ 小 1 時 } & 男子 & $21.4 \pm 3.1$ & $21.8 \pm 4.2$ & $19.6 \pm 2.4$ & $21.5 \pm 3.34$ \\
\hline & 女子 & $21.5 \pm 3.2$ & $21.5 \pm 3.6$ & $21.2 \pm 3.4$ & $21.0 \pm 3.22$ \\
\hline \multirow[t]{2}{*}{ 小 6 時 } & 男子 & $37.6 \pm 7.6$ & $38.8 \pm 8.1$ & $33.0 \pm 4.3$ & $37.9 \pm 7.87$ \\
\hline & \multicolumn{2}{|c|}{ ローレル指数 } & $39.8 \pm 7.3$ & $41.9 \pm 9.0$ & $38.7 \pm 7.64$ \\
\hline \multirow[t]{2}{*}{ 小 1 時 } & 男子 & $132.3 \pm 11.9$ & $139.0 \pm 15.9$ & $136.1 \pm 5.0$ & 135.3 \\
\hline & 女子 & $136.9 \pm 12.5$ & $139.5 \pm 14.9$ & $130.2 \pm 9.6$ & 134.5 \\
\hline \multirow[t]{2}{*}{ 小 6 時 } & 男子 & $123.8 \pm 17.8$ & $132.7 \pm 21.5$ & $124.7 \pm 7.5$ & 126.1 \\
\hline & 女子 & $125.7 \pm 16.9$ & $128.7 \pm 18.3$ & $126.9 \pm 15.1$ & 124.1 \\
\hline
\end{tabular}

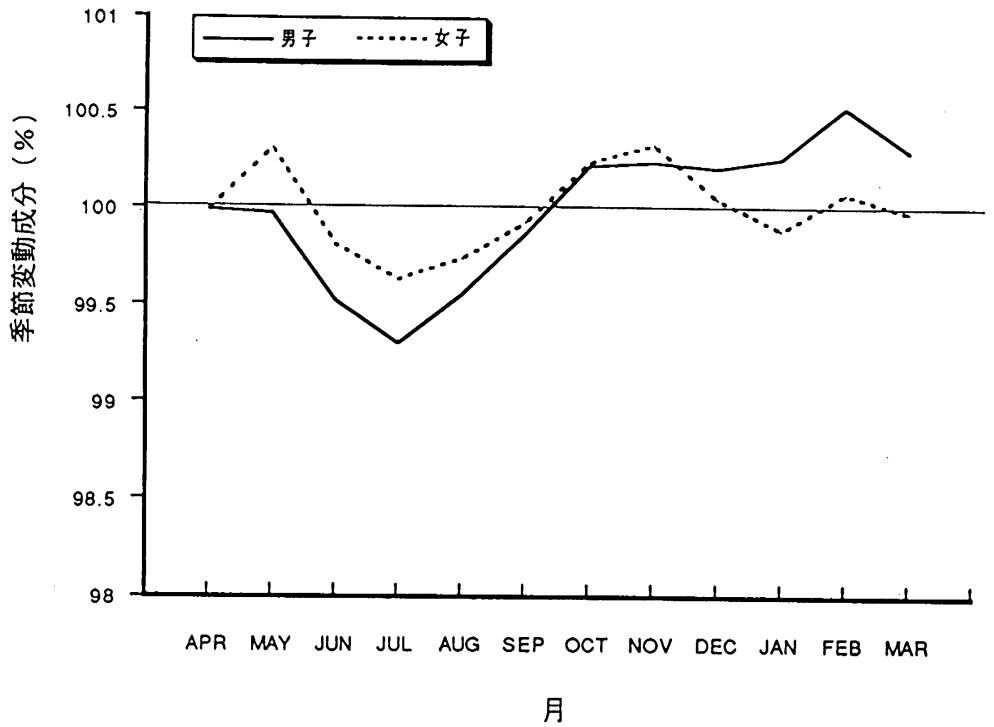

図 2 東京都 A 小学校児童の体重季節変動成分 
べ身長が 4 から $6 \mathrm{~cm}$ ほど，体重では 2 から $5 \mathrm{~kg}$ ほ ど小さく，小柄な傾向が見られたが，口ーレル指 数は全国平均とほぼ一致していた。一方，女子で は，身長，体重とも若干大きな值がみられた。C小 男女の傾向は, 被検者数が少ないことによると考

\section{えられる。}

2. 体重季節変動のパターン, 変動幅について 図 2, 図 3, 図 4 は時系列解析によって抽出さ れた $\mathrm{A}$ 小, $\mathrm{B}$ 小, $\mathrm{C}$ 小児童の季節変動成分である. 72 力月分の季節变動成分を月別に平均し，平均的

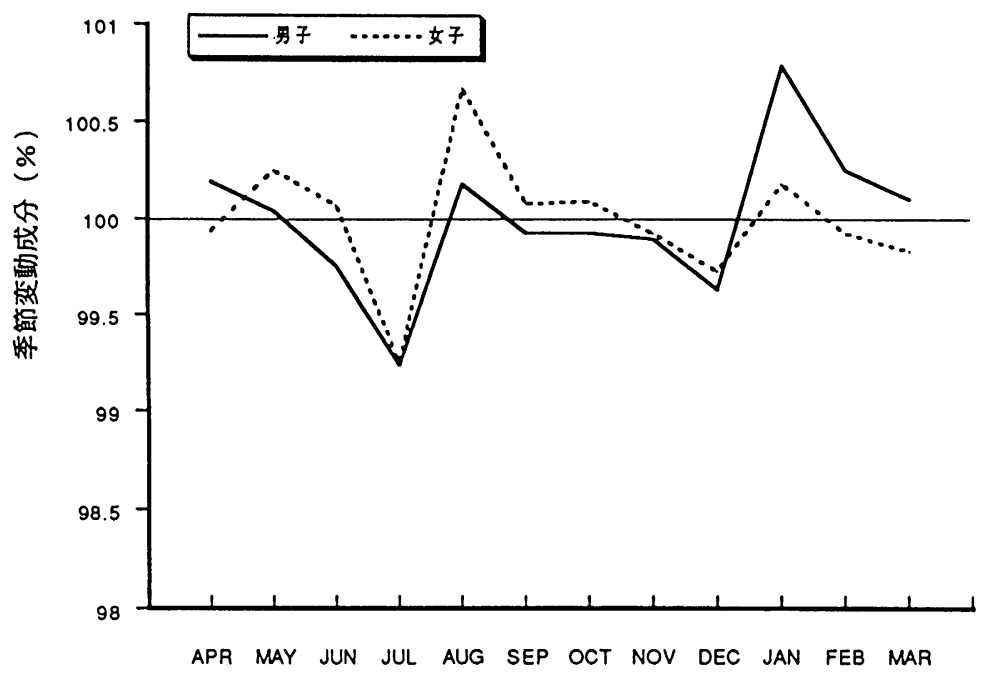

月

図 3 群馬県 $\mathrm{B}$ 小学校児童の体重季節変動成分

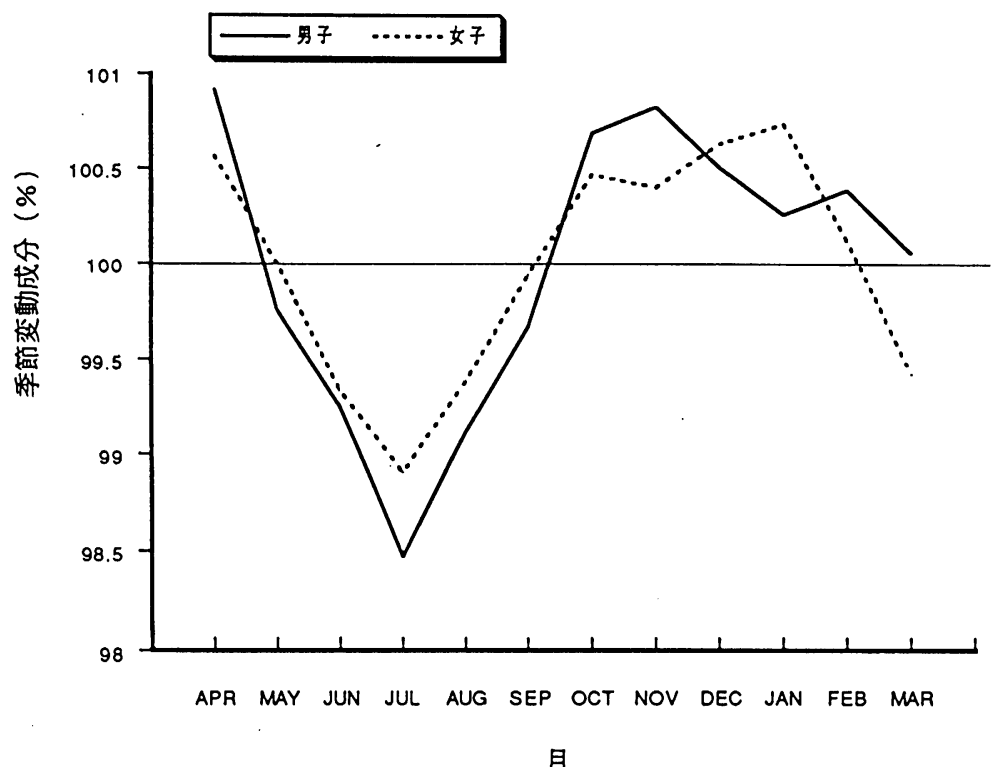

図 4 栃木県 C 小学校児童の体重季節变動成分 
な 1 周期の季節変動を求めてある。季節性の検定 では，いずれの地域でも，男女とも高い有意性 （p＜0.0001）を示していた. 変動のパターンにつ いては，各地域に共通に，7月に最低值が現れて いた。 8 月の值は B 小のみで得られ，比較的高い 値であったが，全体的に夏季には低い傾向が観察 された，最高值を示す月は， A 小男子で 2 月，女 子で11月，B 小男子で 1 月, 女子で 8 月, C小男子
で 4 月, 女子で 1 月と異なり, 高い値が共通の季 節に現れる傾向は見られなかった。しかし，A小 女子と B 小女子以外では, 夏に低く, 秋もしくは 冬に高い值を示すパターンが観察された。

季節変動の最高値から最低值を引いて, 季節変 動幅を求めた結果は, A 小男子では $1.24 \%$,女子 では0.70\%，B 小男子で1.55\%，女子で1.42\%，

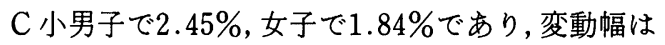
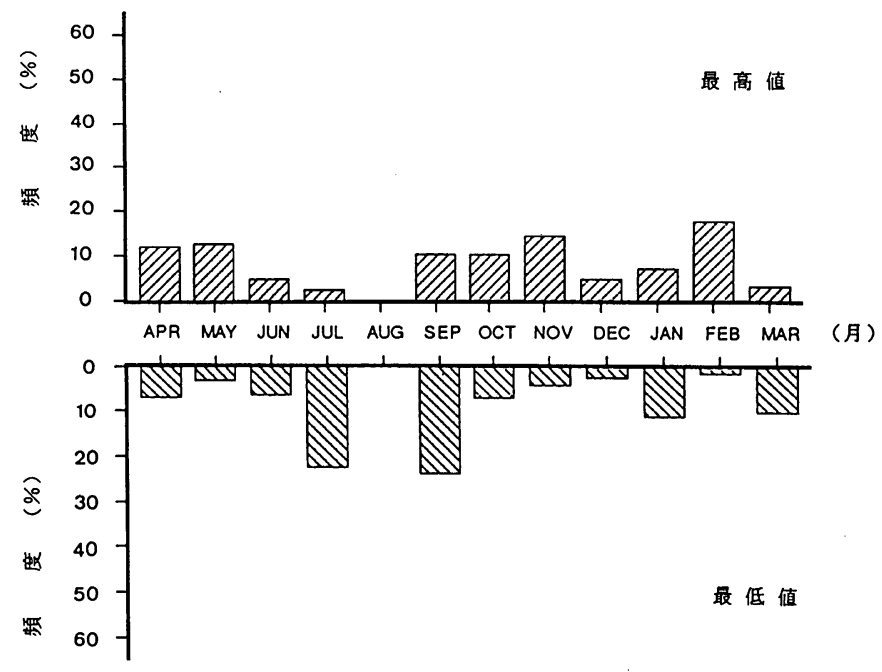

図 5 個人別季節変動成分で最高値, 最低値が出現する月（A 小学校児童）

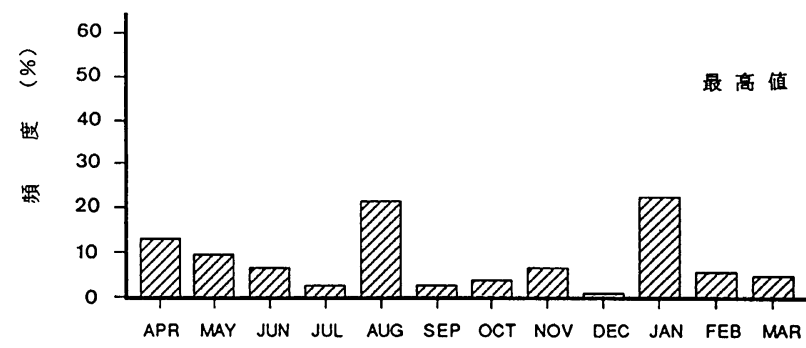

(月)

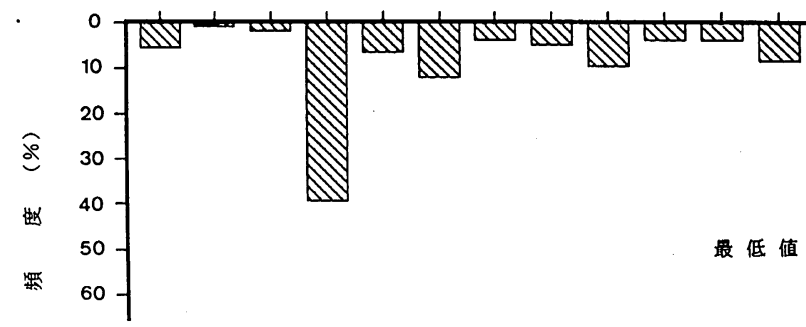

図 6 個人別季節変動成分で最高値, 最低値が出現する月（B 小学校児童） 


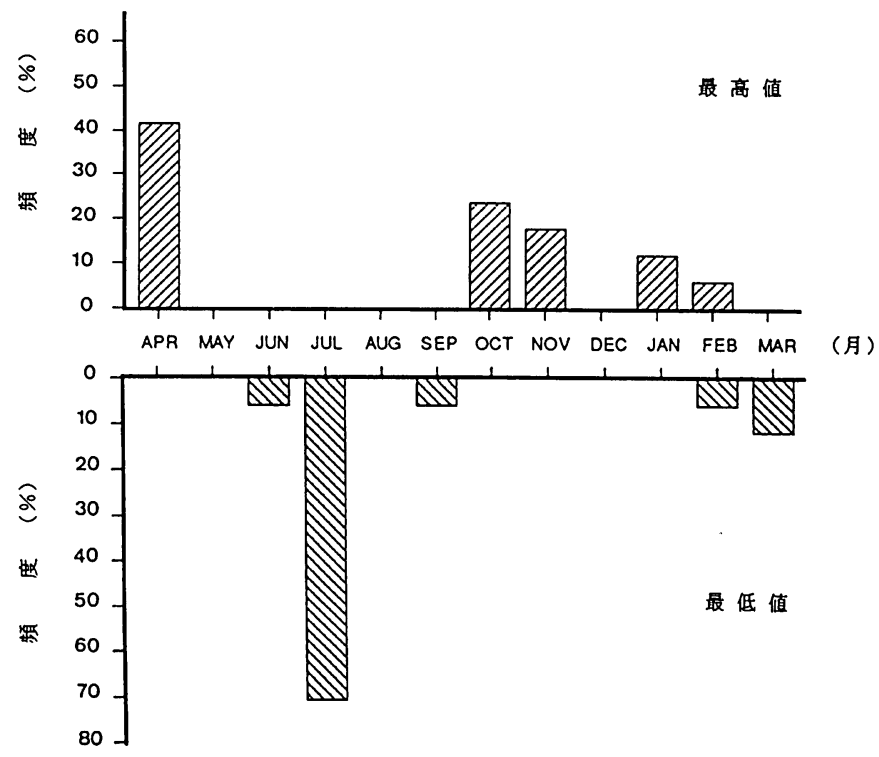

図 7 個人別季節変動成分で最高値, 最低值が出現する月（C小学校児童）

地域別には C 小, $\mathrm{B}$ 小， $\mathrm{A}$ 小の順で大きかった。 また，いずれの地域でも，男子の方が女子ょりも 大きな変動幅を示していた。季節性の検定におけ る $\mathrm{F}$ 值に関しても，同様に性差がみられ，A小の 男子で10.43，女子で5.97, B 小の男子で14.16, 女子で 6.09, C小で男子で20.17，女子で8.29 と， 女子に比べ，男子の方が明らかに高い傾向を示し ていた。

3. 個人別の季節変動パターンについて

個人別に季節変動成分を求め, 季節性の検定を したところ，有意な季節性 $(\mathrm{p}<0.05)$ は，A 小で $80.0 \%, \mathrm{~B}$ 小では $87.9 \%$, C 小では $94.1 \%$ の児童で 認められた，個人別季節変動成分について，最高 值，または最低値が現れる月を求め，その出現傾 向を示したのが, 図 5 , 図6, 困 7 である.A 小, $\mathrm{B}$ 小児童では最高值は年間を通して出現してお り, 特定の季節に特に出現率が高い傾向は認めら れなかった。一方，C小児童では 4 月に $41.2 \%$ の子 どもが最高値を示し，10１1月にも最高值を示す ものが多く見られたが， 5〜9月では最高値を示 すものが見られなかった。最低值に関しては， 7 月に出現する子どもの率がいずれの地域の児童で
も多い傾向が見られ，A小児童では $22.4 \% ， \mathrm{~B}$ 小

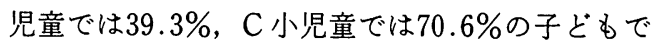
最低值が 7 月に現れていた。

\section{IV 考察}

都市部と農山村部の児童を対象に，体重の季節 変動の地域性について, 集団の季節変動パターン, 個人のパターンのばらつき等の点から検討した。

1. 分析方法について

Bogin (1979)は, グアテマラの学童に拈ける体 重の季節変動を観察し, 増加量の平均值では季節 変動が見られたものの，個人別には季節変動は見 られなかったと報告している。従来の季節変動の 分析では増加量の平均値を求めて季節性を検討し たものがほとんどである，各個人の体重の発育測 定值には，発育スパート，季節変動等の周期的変 動, 測定誤差を含む不規則変動など, 複雑な変動 が含まれており（Togoら：1982），増加量を指標 とした場合，たとえ季節変動が存在したとしても， 複雑な変動の中から季節变動のみを識別し, 抽出 することは困難であった。

本研究では, 長期間の月次データについて, 時 
系列解析を用いて季節変動を抽出した。この方法 では発育スパートなど比較的長期的な变動はトレ ンド成分に含をれ，周期性を持たない短期的変動 は不規則成分に含まれるため, 図 1 に示すように, 発育スパートや測定誤差などの影響が除かれた季 節変動が抽出できたと考えられる，個人別のデー タについて, 季節変動を求めた結果, 多くの子ど もで有意な季節変動が認められた。これらを総合 的に考えて, 複雑な変動を含む時系列発育データ を分析する場合，この方法は有効であるといえよ 丂.

2. 地域別の季節変動パターンについて

各校児童の体重平均値の季節性については, 季 節性の検定で高い有意性を示したことから，各校 の男女とも有意な季節変動が存在したといらこと ができる. 地域別には男女の変動は類似したパ ターンを示していた(因 2, 図 3, 四4). 夏季に は, A 小, B 小, C 小のいずれにも低い值が出現 しており, 最低值はどのグループでも 7 月に現れ ていた。一方, 最高値を示す月はグルーブ毎に異 なっており，共通の月に出現する傾向は見られな かった. 1940年代, 50年代に, 高橋(1948), 小林 ら（1955）は，5月から6月にかけて増加量が小 さく，10月から11月にかけて増加量が最も大きい 傾向を報告している。本研究で用いた方法で季節 変動を求めた場合， 7 月に最低値が得られたとい うことは, その前に増加量の小さい時期があった ことを示すため, 低い值を示す時期としては高橋 らと一致しているものと解秎できう。ここでは, $\mathrm{A}$ 小と C小に関しては 8 月の測定值は補間值で あるため, 8 月の季節変動值は得られていない。 また， B 小で 8 月の值が比較的高い值を示してい たが，8月の体重計測は夏休及終了後に行われた ため, 測定の時期が通常の月より遅くなる傾向が あった.分析では等間隔として処理したため, B 小 の 8 月の季節変動値は過大評価している可能性が 大きい.このようなことを考慮した場合, 高い季 節変動値が現れる月には地域差, 性差があったが, 低い值はいずれの地域でも夏季に現れることが示 された。
また, 各月の小さな変動については, 偶然変動 の可能性もあり, 意味付けは困難であった。

3. 季節変動の変動幅について

季節変動の最高值と最低值の差である変動幅に ついては, 農山村部の B 小, C小に比べ, 都市部 の A 小の方が小さい傾向が見られた。特に C 小で は男子では2.45\%, 女子では1.84\%であったのに 対し，A 小男子では $1.24 \%$, 女子で $0.70 \%$, 変 動幅は $1 / 2$ ほどであった。このように变動幅の地域 差が観察された原因は，ここでは明らかにされな かったが，成育環境の違いが影響している可能性 は十分考学られる。たと充は，東京では気候的に は B 小, C小のある高原に比べ, 冬は比較的温暖 であるが，夏は高温になる。しかし，多くの家庭 で冷暖房が完備されていると考学られ，生活空間 の温度環境は年間を通して比較的一定に保たれて いる可能性がある。 また, 都市部では放課後に学 習塾やスポーックラブなどに通う子どもが多く, 農山村部の子どもとは異なった, 都市特有の複雑 な環境が存在すると思われる。このように生活パ ターンの違いが体重の季節変動のパターンや変動 幅の違いに表れていることも考えられよう。

ところで男女間では，季節性の検定の F 值がい ずれの地域でも, 男子の方が女子より明らかに高 い傾向を示していた。各地域では男女とも同様な 環境で生活していると考えられるが，女子よりも 男子の方が, 発育過程の変動が月の効果によって 説明される率が大きいことが示唆された。体重季 節変動に性差があるかどらかは, さらに多くの地 域のデータを検討する必要がある。しかしながら， 季節変動の変動幅も地域別には常に女子より男子 の方が高い値を示していたこともあり，興味深い 結果である.

4. 個人別季節変動のパターンについて 個人別の季節変動成分で, 最高値と最低值が出 現する月について検討した（図 5, 図6, 図 7 ）. 最高値が出現する月は, C小では 4 月に特に多い 傾向が見られたものの，A 小，B 小ではばらつき が見られ, 変動のピークが出現する季節が一致す る傾向は認められなかった。一方, 最低值を示す 
月は特に 7 月に集中し，特に $\mathrm{B}$ 小， $\mathrm{C}$ 小では，そ れぞれ $39.3 \% ， 70.6 \%$ にる゙，顕著であった。最 高値や最低值の出現の傾向からみて，A 小児童で は，他の小学校児童に比べ，季節性が明確でない 傾向がうかがえた。この結果は, 地域別の季節変 動の分析で観察された，A 小では季節变動幅が小 さい傾向がある，という結果とともに，A 小児童 の季節性が B 小，C小に比べ，弱い傾向を示して いると解釈できよう。

いずれの地域でも 7 月に最低の季節变動值を示 すことが観察され，その傾向は，個人別の季節変 動パターンにも明らかに示されていたが，その原 因として大きく分けて，1）基礎代謝の季節変動, 2）身体活動によるエネルギー消費の増加，3）エ ネルギー摂取の減少，の 3 点が挙げられよう

(Forbes: 1986, Holliday : 1986).

まず, 基礎代謝の変動に関しては, Karvonen ら (1952), 上田ら (1954), Osiba (1957), Fujimoto ら（1965）が，夏には基礎代謝量が低く，冬には 高い傾向を明らかにしている。これは，夏季には 基礎代謝によるエネルギー消費が減少し，冬季に は増加することを意味し，本研究で観察された体 重の季節変動の傾向とは逆の傾向を示すものであ る。また，身体活動によるエネルギー消費の変化 に関しては，夏では日照時間が長いことから，活 動時間が增加する可能性が考えられる。しかしな がら，児童は基本的に小学校の時間割で活動して おり，7月に特に最低値をもたらす原因としては 考光にくい。

一方，夏季の高温多湿の環境は，水分摂取の増 加と食欲の低下をもたらし，夏バテの状態を引き 起こすことがょくある，季節変動の最低値が夏季 に観察された原因として，このような食欲の低下 によるエネルギー摂取の減少が生じている可能性 は高いと考えられる。また，発有期に外的環境か ら強いストレスを受け，発育遅滞が扣きると，ス トレスの解消後にそれを補償するように，追いつ き発育が見られることが知られている(Tanner： 1986).このよらなことから，体重の発育では，夏 期の減速に対する，その後の追いつき発育が繰り
返されており，季節変動として現れていることが 考党られた。

\section{V 結 論}

東京都在住の児童と, 群馬県, 栃木県の農山村 部に在住の児童, 計 249 人を対象に，体重発育に拧 ける季節変動のパターン, 変動幅等を比較し, 季 節変動の地域性を検討した。結果より，次のよう な知見が得られた。

1）時系列解析の一つであるセンサス局法を用 いて， 6 年間の体重発育データから季節变動成分 を求めたところ，多くの子どすで有意な季節性が 確認された。時系列発育データを分析するらえで, この方法は有効であると考えられた。

2）いずれの地域の児童も季節性は高度に有意 であり，最低值は 7 月に共通に出現する傾向が見 られた。一方, 高い季節変動値を示す月は地域別・ 性別に異なる傾向が見られた。

3）季節变動幅は, 農山村部の B 小, C 小児童に 比べ，東京都 A 小児童では小さい傾向を示し，こ れには，両地域の子どもの成育環境の違いが影響 していると思われた。

4）個人別の季節変動では, 最高值を示す月はば らつきが大きく，一定の季節に出現する傾向は見 られなかった。一方，最低値を示す月は夏季（特 に7月）に集中する傾向が観察された。 その傾向 は， B 小， C 小で特に顕著であり， $\mathrm{A}$ 小では季節 性が弱い傾向が見られた。

5）男女間では, 分散分析による季節性の検定に おいて，女子の F 值に比へ，男子の F 值の方が明 らかに高い値を示しており，体重の季節変動に性 差がある可能性がうかがえた。

謝辞：本稿を終えるにあたり, 終始ご指導とご助言 を賜りました東京大学教育学部健康教育学研究室東郷 正美教授に深くお礼を申し上げます。

\section{文献}

Abdullah, M. \& Wheeler, E.F. (1985): Seasonal variations, and the intra-household distribution of food in a Bangladeshi Village, Am. J. Clin. Nutr, 41, 1305-1313 
Bogin, B. (1979): Monthly changes in the gain and loss of growth in weight of children living in Guatemala, Am. J. Phys. Anthrop, 51, 287-292

Brown, K.H., Black, R.E. \& Becker, S. (1982): Seasonal changes in nutritional status and the prevalence of malnutriton in a longitudinal study of young children in rural Bangladeshi, Am. J. Clin. Nutr, 36, 303-313

Forbes, G.B. (1986) : Body composition in adolescence. In Falkner, F. \& Tanner, J.M., ed., Human Growth, Volume 2, 119-146, W.Y., Plenum Press

Fujimoto, S. \& Watanabe, T. (1965): Seasonal variation of energy metabolism, Acta Med. Nagasaki, 10, 1-11

Hauspie, R.C. \& Pagezy, H. (1989): Longitudinal study of growth of African babies; An analysis of seasonal variations in the average growth rate and the effects of infectious diseases on individual and average growth patterns, Acta Pœdiatr. Suppl, 350, 37-43

Holliday, M.A. (1986): Body composition and energy needs during growth. In Falkner, F. \& Tanner, J.M., ed., Human Growth, Volume 2, 101 -117 , N.Y., Plenum Press

Jalil, F., Karlberg, J., Hanson, L.A. \& Lindblad, B. S. (1989): Growth disturbance in urban area of Lahore, Pakistan, related to feeding patterns, infections and age, sex, socio-economic factors and seasons, Acta Pœdiatr. Suppl, 350, 44-54

Karvonen, M.J. \& Niemi, M. (1952): The accuracy of basal metabolism determination in the clinical laboratory, Scand. J. Clin. Lab. Invest, 4, 112-114

小林 収, 尾崎久雄, 駕尾滋夫, 林功, 池田筆子
（1955）：学童の体重発育の季節的变動, 小児保健研 究, $14,178-182$

Osiba, S. (1957): The seasonal variation of basal metabolism and activity of thyroid gland in man, Jap. J. Physiol, 7, 355-365

Pollitt, E. \& Arthur, J. (1989): Seasonality and weight gain during the first year of life, Am. J. Hum. Biol, 1, 747-756

Prentice, A.M., Whitehead, R.G., Roberts, S.B. \& Paul, A.A. (1981) : Long-term energy balance in child-bearing Gambian women, Am. J. Clin. Nutr, 34, 2790-2799

SAS Institute (1984) : SAS/ETS User's Guide, 147 $-176$

高橋英次 (1948)：体重発育の季節的動摇，民族衛生， 15(1), $8-18$

Tanner, J.M. (1986): Growth as a target-seeking function: Catch-up and catch-down growth in man. In Falkner, F. \& Tanner, J.M., ed., Human Growth, Volume 1, 167-179, N.Y., Plenum Press

Togo, M. \& Togo, T. (1982): Time-series analysis of stature and body weight in five siblings, Ann. Hum. Biol, 9, 425-440

東郷正美（1981）：発育研究の最新の展開一個人の発 育之集団の発育，医学のあゆみ，118，395-402

Trowbridge, F.L. \& Newton, L.H. (1979): Seasonal changes in malnutrition and diarrheal disease among preschool children in E1 Salvador, Am. J. Trop. Med. Hyg, 28, 135-141

上田豊晴, 大黒芳太郎, 千野和男, 江藤一明 (1954)： 日本人の基礎新陳代謝の研究，第 15 報。基礎新陳代 謝の季節変動について。 その 2 , 医学と生物学, 32(6), $282-284$

（受稿 1992．11．11） 